\title{
Characterisation of volatile compounds produced by bacteria isolated from the spoilage flora of cold-smoked salmon
}

\author{
J. J. Joffraud ${ }^{\star, a}$, F. Leroi ${ }^{a}$, C. Roy ${ }^{\mathrm{a}}$ and J. L. Berdagué ${ }^{b}$ \\ a IFREMER, Laboratoire de Génie Alimentaire, BP 21105, 44311 Nantes Cedex 03, France \\ ${ }^{b}$ INRA de Theix, Station de Recherches sur la Viande, 63122 Saint Genès Champanelle, France \\ *: Corresponding author : Tel.: +33-2-40-37-4088; fax: +33-2-40-37-4071; email: joffraud@ifremer.fr
}

\begin{abstract}
:
This study investigated the volatile compounds produced by bacteria belonging to nine different bacterial groups: Lactobacillus sake, L. farciminis, L. alimentarius, Carnobacterium piscicola, Aeromonas sp., Shewanella putrefaciens, Brochothrix thermosphacta, Photobacterium phosphoreum and Enterobacteriaceae isolated from cold-smoked salmon. Each bacterial group was represented by several strains. In addition, combinations of the groups were examined as well. Sterile blocks of coldsmoked salmon were inoculated, vacuum-packed and stored at $6^{\circ} \mathrm{C}$. After 40 days of storage at $6^{\circ} \mathrm{C}$, aerobic viable count and $\mathrm{pH}$ were recorded, the volatile fraction of the samples was analysed by gas chromatography-mass spectrometry (GC-MS), and spoilage was assessed by sensory evaluation. Among the 81 volatile compounds identified by GC-MS, 30 appeared to be released as a result of bacterial metabolism. Some of the effects of inoculated bacterial strains on the composition of the volatile fraction seemed to be characteristic of certain bacterial species. Sensory analysis showed relationships between bacteria, the composition of the volatile fraction and the organoleptic quality of smoked salmon.
\end{abstract}

Keywords: Cold-smoked salmon; Spoilage; Bacteria; Volatile compounds 


\begin{abstract}
This study investigated the volatile compounds produced by bacteria belonging to nine different bacterial groups: Lactobacillus sake, Lactobacillus farciminis, Lactobacillus alimentarius, Carnobacterium piscicola, Aeromonas sp, Shewanella putrefaciens, Brochothrix thermosphacta, Photobacterium phosphoreum and Enterobacteriaceae isolated from cold-smoked salmon. Each bacterial group was represented by a five strains culture. In addition, five combinations of these different groups were constituted from the previous cultures. Sterile blocks of cold-smoked salmon were inoculated with these cultures, vacuumpacked and stored at $6^{\circ} \mathrm{C}$. After 40 days of storage at $6^{\circ} \mathrm{C}$, total aerobic viable count and $\mathrm{pH}$ were recorded, the volatile fraction of the samples was analysed by gas chromatography-mass spectrometry (GC-MS), and spoilage was assessed by sensory evaluation. Among the 81 volatile compounds identified by GC-MS, 30 appeared to be released as a result of bacterial metabolism. Some of the effects of inoculated bacterial strains on the composition of the volatile fraction seemed to be characteristic of certain bacterial species. Sensory analysis showed relationships between bacteria, the composition of the volatile fraction and the organoleptic quality of smoked salmon.
\end{abstract}

Keywords : Cold-smoked salmon; Spoilage; Bacteria; Volatile compounds. 


\section{Introduction}

Cold-smoked salmon is a lightly-preserved fish product of considerable economic importance. Although salting and smoking were formerly used exclusively for preservative purposes, these techniques are increasingly applied for their gustatory effects. As a result, these products are now only lightly cured. However, this trend in cold-smoked fish processing could involve health risks (Huss et al., 1995; Heinitz and Johnson, 1998), especially from the presence of Listeria monocytogenes (Ben Embarek, 1994; Jorgensen and Huss, 1998). Moreover, the sensory characteristics of lightly cured products are often degraded with textural changes and the occurrence of off-odours after only 2 or 3 weeks of storage (Rakow, 1977; Schulze and Zimmerman, 1983; Nieper, 1986; Hildebrandt and Erol, 1988; and Truelstrup Hansen et al., 1995, 1996). Such spoilage effects are usually indicative of microbial activity. In recent years, some studies have considered the specific bacterial flora of cold-smoked salmon and determined the main taxonomic groups that occur frequently in this product (Leroi et al., 1998; Paludan Müller et al., 1998; Truelstrup Hansen et al., 1998). However, none of these micro-organisms has been implicated so far in sensory changes during chilled storage of cold-smoked fish.

The identification of the bacteria responsible for the spoilage of smoked salmon is important to allow (i) a better understanding of the mechanisms involved in spoilage and of any changes in the product during the salting and smoking process that limit the growth of spoilage flora; (ii) the development of convenient means of counting the spoilage flora; and (iii) the design of a model for predicting deterioration in the quality of smoked fish products.

The present study investigated the spoilage potential of bacteria isolated from smoked salmon (Leroi et al., 1998) and known to be present throughout the cold storage of this product. 
Spoilage potentials were assessed by analysing the compositions of the volatiles released from inoculated, spoiled, cold-smoked salmon.

\section{Materials and methods}

\section{$\underline{\text { Isolates }}$}

Isolates were selected from the bacterial collection of the laboratory among strains belonging to the taxonomic groups : Lactobacillus sake, Lactobacillus farciminis, Lactobacillus alimentarius, Carnobacterium piscicola, Aeromonas sp, Shewanella putrefaciens, Brochothrix thermosphacta, Photobacterium phosphoreum and Enterobacteriaceae. Except the 3 isolates for Enterobacteriaceae, each group was represented by a mixture of 5 strains. In addition, five combinations of different species were also provided (Table 1).

Combination 1 included gram-negative bacteria in an equal ratio; combination 2, all the bacteria except Lactobacillus spp.; combination 3, all lactic acid bacteria together in an equal ratio; combination 4 , all the species together, with gram-negative bacteria comprising $75 \%$ of the total; and combination 5, all the species together, but in an inverse ratio to combination 4, with gram-positive strains ( $\mathrm{LAB}+$ B. thermosphacta) comprising $75 \%$ of the total.

Table 1: Compositions of the inocula composed of mixed cultures.

\begin{tabular}{lrrrrr}
\hline \multicolumn{1}{c}{ Species } & \multicolumn{5}{c}{ Combinations } \\
\hline \\
\cline { 2 - 6 } Shewanella putrefaciens & $\mathrm{X}$ & $\mathrm{X}$ & & $\mathrm{X}$ & $\mathrm{X}$ \\
Brochothrix thermosphacta & & $\mathrm{X}$ & & $\mathrm{X}$ & $\mathrm{X}$ \\
Photobacterium phosphoreum. & $\mathrm{X}$ & $\mathrm{X}$ & & $\mathrm{X}$ & $\mathrm{X}$ \\
Aeromonas sp. & $\mathrm{X}$ & $\mathrm{X}$ & & $\mathrm{X}$ & $\mathrm{X}$ \\
Lactobacillus alimentarius & & & $\mathrm{X}$ & $\mathrm{X}$ & $\mathrm{X}$ \\
Lactobacillus farciminis & & & $\mathrm{X}$ & $\mathrm{X}$ & $\mathrm{X}$ \\
Lactobacillus sake & & $\mathrm{X}$ & $\mathrm{X}$ & $\mathrm{X}$ \\
Carnobacterium piscicola. & & $\mathrm{X}$ & $\mathrm{X}$ & $\mathrm{X}$ & $\mathrm{X}$ \\
\hline
\end{tabular}




\section{$\underline{\text { Sterile cold-smoked salmon model system }}$}

A sterile model system developed by an aseptic process and ionisation as described by Joffraud et al. (1998) was used as substrate. The composition of this model system was 58\% water, $18 \%$ lipids, $4.8 \% \mathrm{NaCl}$ in water phase and $0.62 \mathrm{mg} 100 \mathrm{~g}^{-1}$ phenols and the initial $\mathrm{pH}$ was 6.15 .

\section{Culture and inoculation procedure}

Strains stored at $-80^{\circ} \mathrm{C}$ were removed from cryovials and inoculated into appropriate culture media. C. piscicola strains were grown in Elliker broth (Elliker et al., 1956) (Biokar Diagnostics, Beauvais, France), Lactobacillus spp isolates in Man, Rogosa and Sharpe (MRS) broth (de Man et al., 1960) (Merck, Darmstadt, Germany), and the other strains in brain-heart infusion (BHI) broth (Difco Laboratories, Detroit, MI, USA).

Strains were grown at $20^{\circ} \mathrm{C}$ for 3 days and then in subculture at $20^{\circ} \mathrm{C}$ for 2 days. Five isolates belonging to the same genus or species were mixed and the mixture was twice diluted tenfold in sterile peptone water.

The second dilution of the mixture was used to inoculate cold-smoked salmon pieces of the model system. To achieve an inoculation rate of approx. $10^{5}$ cells/g, $6.6 \mathrm{ml}$ of culture at $10^{7}$ cells/ml were added to $330 \mathrm{~g}$ of sterile cold-smoked salmon in a sterile flask and then stirred to homogenise the mixture. A control was created by replacing the inoculum with sterile peptone water.

The inoculated samples and the control were then vacuum-packed in polyamide/polyethylene bags (PA/PE 20/70, Euralpac, Alfo, Germany), the permeability for $\mathrm{O}_{2}$ was $40-50 \mathrm{~cm}^{3} / \mathrm{m}^{2}$ and for $\mathrm{CO}_{2}, 146 \mathrm{~cm}^{3} / \mathrm{m}^{2}$ in $24 \mathrm{~h}, 1 \mathrm{~atm}$ at $23^{\circ} \mathrm{C}, 75 \%$ r.F. Before being vacuum-packed, salmon 
pieces were wrapped in an aluminium sheet to prevent volatile compounds from the bag material being absorbed by the product.

Each batch inoculated with a single bacterial group was distributed in 4 bags: 2 for volatile compound analysis, one for bacteriological and sensory analyses and an additional one if needed. Samples were stored at $6^{\circ} \mathrm{C}$ for 40 days before being withdrawn for GC-MS analysis, enumeration of bacteria and sensory evaluation.

\section{Enumeration of bacteria and $\mathrm{pH}$ measurement}

The total aerobic viable count was determined on Long and Hammer's medium containing $1 \% \mathrm{NaCl}$ (van Spreekens, 1974). Thirty grams of salmon samples were homogenised and diluted in $120 \mathrm{ml}$ of chilled physiological saline containing $0.85 \%(\mathrm{w} / \mathrm{v}) \mathrm{NaCl}$ and $0.1 \%(\mathrm{w} / \mathrm{v})$ tryptone (Biokar) for 2 min in a stomacher (Lab. Blender, London, UK). After 30 min at room temperature, the homogenate was serially diluted ten-fold in physiological saline, and $0.1 \mathrm{ml}$ of each appropriate dilution was spread-plated in duplicate on Long and Hammer's medium. Agar plates were incubated aerobically at $15^{\circ} \mathrm{C}$ for 5 days.

The $\mathrm{pH}$ value was measured in the five-fold dilution flesh with a $\mathrm{pH}$ meter (Mettler Delta 320, AES Laboratoire, Combourg, France).

\section{$\underline{\text { Sensory evaluation }}$}

Sensory evaluation was carried out by 7 trained panellists who sniffed the samples and chose free descriptors to define odours. According to this evaluation, they had to classify the samples into the following three groups defined by spoilage level: level 1, no spoilage noted ; level 2, weak spoilage ; level 3, strong spoilage. 
The sample condition was regarded as spoiled when at least $50 \%$ of the panellists rated it in level 3.

\section{Volatile compounds analysis.}

3.6 g portions of cold-smoked salmon were diced into approximately $5 \mathrm{~mm}$-sided cubes. Each diced portion was placed in a glass extraction cartridge of diameter $25 \mathrm{~mm}$ and length 135 mm (glass extraction cartridge M 13, Etablissements Mailleres, Aubière 63170 France). The volatile components desorbing from the salmon were extracted at room temperature $\left(20^{\circ} \mathrm{C}\right)$ by

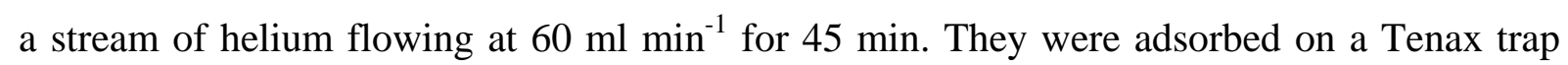
(Tenax Supelco, Alltech, Deerfield, IL. 60015, USA) of 60/80 mesh, $80 \mathrm{~mm}$ long, held at $25^{\circ} \mathrm{C}$. The injection of volatile components into a gas chromatograph (Hewlett Packard 5890 series II, H.P., F 91947, Les Ulis, France) coupled to a mass spectrometer (Hewlett Packard 5791 A) was achieved by flash thermal desorption from the trap at $250^{\circ} \mathrm{C}$ with a desorption concentration injection system (DCI, DELSI Instruments, 92150 Suresnes, France). The components were then separated on a $60 \mathrm{~m}$ x $0.32 \mathrm{~mm}$ capillary column coated with a $1 \mu \mathrm{m}$ film of DB5 (Supelco, C.H.- 1196, Gland, Switzerland) using helium as carrier gas with a flow rate for injection through the column of $1 \mathrm{ml} \mathrm{min}^{-1}$. The chromatograph oven was programmed for $5 \mathrm{~min}$ at $40^{\circ} \mathrm{C}$, followed by a rise to $200^{\circ} \mathrm{C}$ at a rate of $3^{\circ} \mathrm{C}$ per min. Volatile components were detected by mass spectrometry with electron impact at $70 \mathrm{Ev}$ and then identified by comparison of their experimental spectra with those in four data banks: NBS 75K, 1994 ; NIST/EPA/MSDC, 1996 (Royal Society of Chemistry, Milton road, Cambridge

CB4 4WF, UK) ; NIST/EPA/NIH, 1996 (Mass spectral search program, National Institute of Standard and Technology, Gaithersburg, MD. 20899, USA) ; Whiley 275 K, 1996. Their experimental Kovats indices (Tranchant, 1982) were compared with those in the data bank of 
Kondjoyan and Berdagué (1996). Peak areas of the volatile compounds expressed in arbitrary units of abundance (a.u.a) were integrated from the total ionic count.

\section{$\underline{\text { Statistical analyses }}$}

Mean, median, minimum and maximum values were calculated for the volatile compounds. Principal component analysis (PCA) was performed on normalised data (Statistica, 1997) to study the effect of inoculated strains on these volatile compounds. This analysis was done from a 14-line (13 inoculated samples + the control) x 30-column (30 volatile compounds) matrix.

\section{Results}

\section{Bacterial growth and pH}

As the salmon inoculated with $P$. phosphoreum was contaminated by other bacteria, this sample was not analysed, and no results were obtained for this bacterium. Bacterial counts and the $\mathrm{pH}$ of other samples at the end of the storage period are shown in Table 2.

No bacteria were recovered from the control sample. Lactobacillus spp. counts and those for Lactobacillus-containing combinations 3, 4, and 5 reached about $8.5 \log \mathrm{cfu} \mathrm{g}^{-1}$.This growth process led to a decrease in $\mathrm{pH}$ to about 5.7-5.8. Counts for other bacteria reached about 7.0$7.5 \log \mathrm{cfu} \mathrm{g}^{-1}$.and the $\mathrm{pH}$ was in a range from 6.01 to 6.12 . 
Table 2: $\mathrm{pH}$ values and total aerobic viable counts (TVC) of presterilised cold-smoked salmon inoculated with bacteria and stored vacuum packaged at $6^{\circ} \mathrm{C}$ for 40 days.

\begin{tabular}{llc}
\hline Inoculum & pH & TVC (log cfu g-1) \\
\hline Control & 6.13 & 0 \\
Carnobacterium piscicola. (Car) & 6.10 & 7.5 \\
Lactobacillus alimentarius (Lba) & 5.83 & 8.4 \\
Lactobacillus farciminis (Lb) & 5.63 & 8.5 \\
Lactobacillus sake (Lbs) & 5.77 & 8.5 \\
Aeromonas sp. (Aer) & 6.01 & 7.5 \\
Shewanella putrefaciens (She) & 6.12 & 7.1 \\
Brochothrix thermosphacta (Bro) & 6.03 & 6.8 \\
Enterobacteriaceae (Ent) & 6.11 & 7.2 \\
Combination 1 (M1) & 6.07 & 6.9 \\
Combination 2 (M2) & 6.12 & 7.3 \\
Combination 3 (M3) & 5.71 & 8.6 \\
Combination 4 (M4) & 5.69 & 8.4 \\
Combination 5 (M5) & 5.77 & 8.5 \\
\hline
\end{tabular}

\section{Sensory evaluation}

The results of the sensory evaluations are shown in Table 3. Most of the samples were regarded as spoiled, with the exception of samples inoculated with C. piscicola, S. putrefaciens, and combination 1.

Samples inoculated with Lactobacillus spp. were considered to be grossly spoiled, as they gave off strong unpleasant odours which were described as "sour", "acid", "pungent", "floorcloth" and "hydrogen sulphide". Samples inoculated with combinations containing Lactobacillus spp. were characterised by the same descriptors, particularly "hydrogen sulphide". 
Table 3: Conditions and odours assigned by a 7 members panel to samples of presterilised cold-smoked salmon inoculated with bacteria and stored vacuum packaged at $6^{\circ} \mathrm{C}$ for 40 days.

\begin{tabular}{lll}
\hline Inoculum & Condition & Sensory descriptors \\
\hline Lactobacillus alimentarius & Spoiled & Pungent, sour \\
Lactobacillus farciminis & Spoiled & Sour, acid, milky, \\
Lactobacillus sake & Spoiled & $\mathrm{H}_{2} \mathrm{~S}$, floorcloth \\
Carnobacterium piscicola & Unspoiled & Butter, caramel, sour, fruity. \\
Aeromonas spp & Spoiled & Amine, socks, floorcloth \\
Shewanella putrefaciens & Unspoiled & Sickly sweet \\
Brochothrix thermosphacta & Spoiled & Blue-cheese, sour, pungent \\
Enterobacteriaceae & Spoiled & Cheese, wine, butter, malty, \\
Combination 1 & Unspoiled & Smoke, wood fire \\
Combination 2 & Spoiled & Socks, pungent, sour, \\
Combination 3 & Spoiled & $\mathrm{H}_{2} \mathrm{~S}$, ham, acid \\
Combination 4 & Spoiled & $\mathrm{H}_{2} \mathrm{~S}$, acid, rancid, \\
Combination 5 & Spoiled & $\mathrm{H}_{2} \mathrm{~S}$, floorcloth \\
\hline & &
\end{tabular}

Salmon inoculated with $S$. putrefaciens was not assessed as spoiled, even though the descriptor "sickly sweet" was used. The "amine" descriptor was cited for Aeromonas spp. The sample inoculated with C. piscicola was characterised by descriptors such as "butter" and "caramel". As these odours were not unpleasant, the sample was not regarded as spoiled. The sample inoculated with $B$. thermosphacta was considered spoiled and was characterised by the descriptor "blue-cheese". 


\section{Volatile compounds from GC-MS analysis}

\section{Volatile compounds of bacterial origin}

One hundred and thirty-five compounds were isolated from samples and the control, most of which were identified although with various degrees of reliability.

Only 30 of the compounds from bacterial origins were taken into consideration. These compounds, which were known to originate from the main microbial catabolic pathways of lipids, carbohydrates and amino acids, are listed in Table 4 according to their main probable origins. Among these compounds, 2-butanone 3-hydroxy-, 2,3-butanedione, 1-butanol 2methyl and 1-butanol 3-methyl were most abundant. About half of the compounds presented a "non-normal" content distribution, indicative of wide variability among the bacterial strains. 
Table 4: Volatile compounds identified in cold-smoked salmon samples inoculated with bacteria and stored vacuum packaged at $6^{\circ} \mathrm{C}$ for 40 days. They are classified according to their most probable origins.

\begin{tabular}{|c|c|c|c|}
\hline Compounds & $\begin{array}{l}\text { Kovats } \\
\text { indices }^{\text {a }}\end{array}$ & $\begin{array}{c}\text { Reliability of } \\
\text { identification }{ }^{\mathrm{b}}\end{array}$ & $\begin{array}{c}\text { Extracted quantities }{ }^{\mathrm{c}} \\
\left(\text { aua } * 10^{-6}\right)\end{array}$ \\
\hline \multicolumn{4}{|l|}{ Amino acid catabolism } \\
\hline 1-propanol, 2-methyl- & 625 & a & $45 ; 0(0-248)$ \\
\hline Butanal, 3-methyl- & 651 & a & 45; 5 (3 -504) \\
\hline Butanal, 2-methyl- & 661 & a & 4; $1(1-15.3)$ \\
\hline 1-butanol, 3-methyl- ${ }^{+}$ & 731 & a & 218; $51(2-1420)$ \\
\hline 1-butanol, 2-methyl- ${ }^{+}$ & 735 & a & $102 ; 18(0-748)$ \\
\hline 2-butenal, 2-methyl- & 741 & c & $3 ; 2(0-13)$ \\
\hline Disulphide, dimethyl- & 746 & $\mathrm{a}$ & $18 ; 6(2-76)$ \\
\hline \multicolumn{4}{|l|}{ Residual glycogen catabolism } \\
\hline 2,3-butanedione (diacetyl) ${ }^{+}$ & 588 & a & 130; 59 (4-632) \\
\hline 2,3-pentanedione & 690 & a & $9 ; 6(4-24)$ \\
\hline 2-butanone, 3-hydroxy- (acetoïne) ${ }^{+}$ & 707 & $\mathrm{a}$ & 219; $51(0-1890)$ \\
\hline 2,3-butanediol & 779 & $\mathrm{a}$ & $5 ; 1(0-21)$ \\
\hline \multicolumn{4}{|l|}{ Fatty acid catabolism } \\
\hline 2-butanone & 600 & $\mathrm{a}$ & 75; 24 (18-225) \\
\hline 1-penten-3-ol & 679 & $\mathrm{a}$ & 31; 28 (18-68) \\
\hline 2-pentanone & 684 & $\mathrm{a}$ & $26 ; 20(15-100)$ \\
\hline 3-penten-2-one & 721 & $\mathrm{~b}$ & $2 ; 2(1-9)$ \\
\hline 2-pentanol & 738 & $\mathrm{~b}$ & $5 ; 5(0-10)$ \\
\hline 3-hexanone & 783 & $\mathrm{a}$ & $2 ; 2(2-6)$ \\
\hline 2-hexanone & 789 & $\mathrm{a}$ & $2 ; 1(1-5)$ \\
\hline Hexanal & 798 & $\mathrm{a}$ & $3 ; 3(1-11)$ \\
\hline 3-hexanol & 811 & & $1 ; 1(0-6)$ \\
\hline 2-heptanone & 888 & $\mathrm{a}$ & $1 ; 1(1-2)$ \\
\hline Nonanal & 1104 & $\mathrm{a}$ & 4; 4 (2-8) \\
\hline Decanal & 1204 & $\mathrm{a}$ & $6 ; 6(4-9)$ \\
\hline \multicolumn{4}{|l|}{ TMAO reduction } \\
\hline Trimethylamine & 503 & $\mathrm{~b}$ & $3 ; 0$ (0-10) \\
\hline \multicolumn{4}{|l|}{ Multiple origins } \\
\hline 2-propanone & 500 & $\mathrm{a}$ & $17 ; 14(8-52)$ \\
\hline 1-propanol & 554 & $\mathrm{a}$ & 52; $14(0-231)$ \\
\hline Acetic acid & 606 & $\mathrm{a}$ & 5; $4(1-16)$ \\
\hline Ethyl acetate & 614 & $\mathrm{a}$ & $40 ; 31(8-82)$ \\
\hline n-propyl acetate & 712 & b & 14; 4 (0-69) \\
\hline Ethyl butanoate & 799 & & $3 ; 2(0-6)$ \\
\hline \multicolumn{4}{|c|}{$\begin{array}{l}\text { The reliability of the identification is indicated by the following letters: a, mass spectrum and } \\
\text { retention time identical to those of an authentic sample; b, mass spectrum and Kovats indices in } \\
\text { agreement with corresponding data in the literature; c, mass spectrum consistent with spectra found in } \\
\text { the literature. } \\
{ }^{c} \text { The extracted quantities: mean; median (minimum-maximum) are expressed in arbitrary units of } \\
\text { abundance * } 10^{-6} \\
{ }^{+} \text {Plentiful compound }\end{array}$} \\
\hline
\end{tabular}




\section{Effect of the bacteria}

Results for principal component analysis are displayed in variable plots and sample plots (Fig. 1 and 2). The variable plot constitutes a graphic representation of the relationships between variables and the two axes. The first three axes accounted respectively for $45 \%, 17 \%$ and $10 \%$ of the total variance of the data. Observations for the first two planes (1-2 and 2-3) indicated that there were 5 groups of samples.

The first group corresponded to samples inoculated with Aeromonas spp. (Aer), Enterobacteriaceae (Ent), S. putrefaciens (She), combination 1 (M1) and combination 2 (M2). This group released the greatest amounts of compounds, such as TMA, disulphide dimethyl, 2,3-butanediol and 2-pentanol.

The second group, in a central position, corresponded to samples inoculated respectively with Lactobacillus alimentarius (Lba), Lactobacillus farciminis (Lbf) and Lactobacillus sake (Lbs).

The third group, composed of samples inoculated with combinations M3, M4, and M5, produced large amounts of compounds, such as n-propyl acetate, 1-propanol, 2-butanone, and ethyl acetate.

The fourth group included the control and the sample inoculated with C. piscicola (Car). Increasing amounts of compounds, such as 2,3-butanedione, 2,3-pentanedione, were found in this sample (Fig. 2A).

Finally, the fifth group comprised the sample inoculated with B. thermosphacta (Bro), which was clearly distinct from the other samples with respect to axis 1 (Fig. 1B). This sample contained the highest amounts of 2-heptanone and 2-hexanone. 

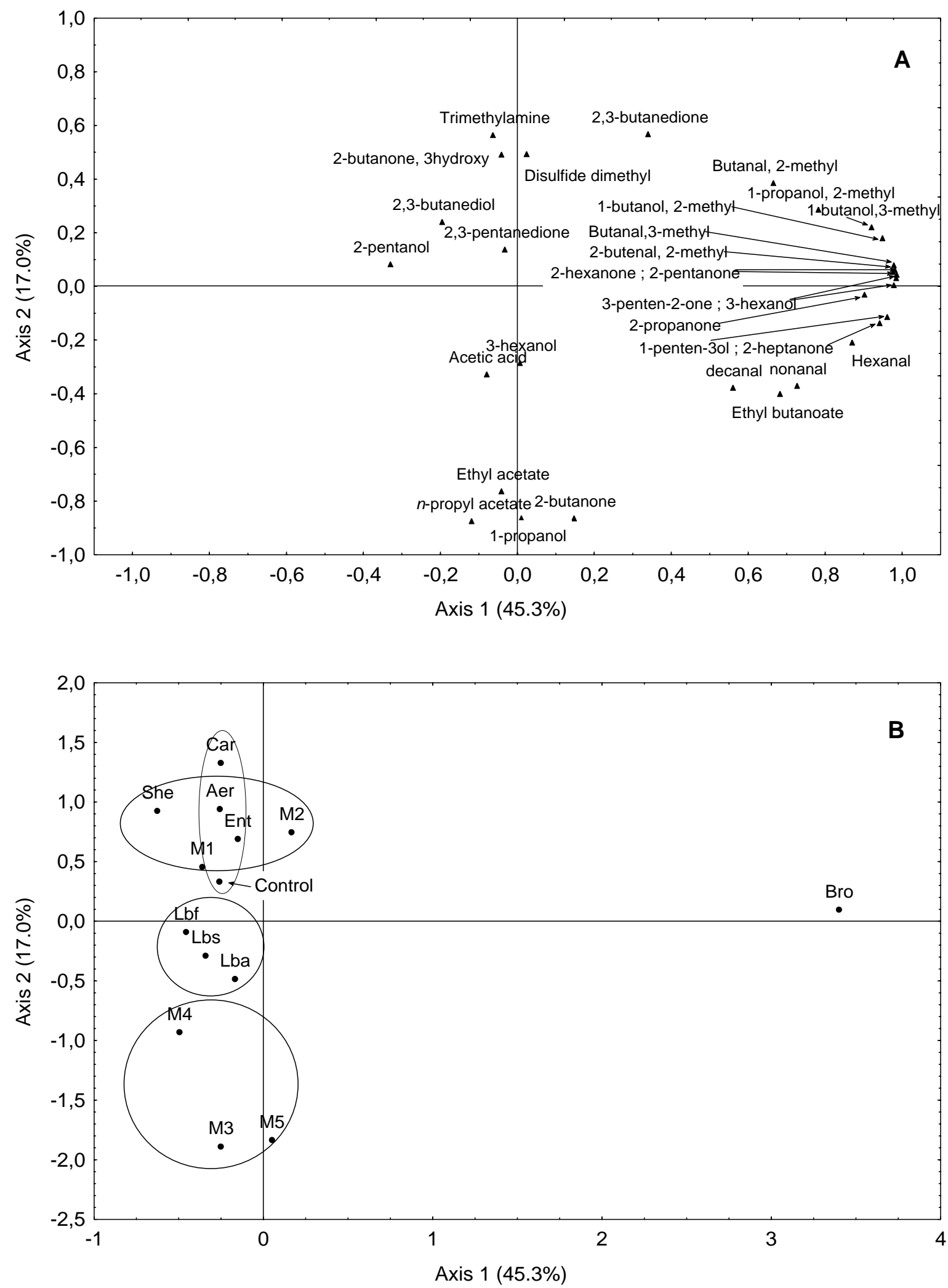

Figure 1 : Principal component analysis of volatile compounds, plane 1-2: (A) variable plot ; (B) sample plot 

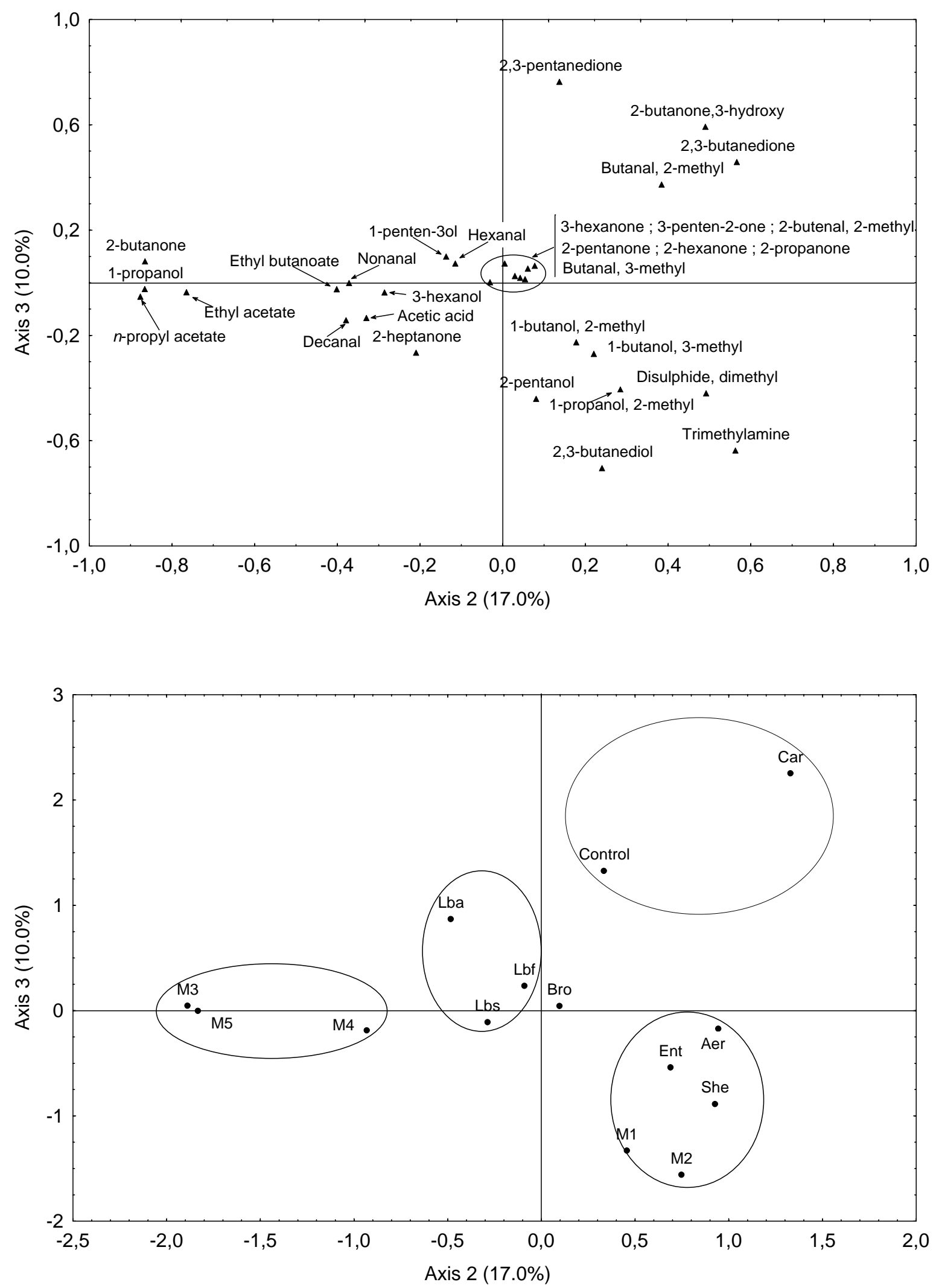

Figure 2 : Principal component analysis of volatile compounds, plane 2-3 : (A) variable plot ; (B) sample plot 


\section{Discussion}

The objective of the study was the investigation of spoilage potential of cold-smoked salmon flora. In this respect, only volatile compounds resulting from the bacterial metabolism were relevant and accordingly only 30 of the 135 compounds identified were considered.

The compositions of some combinations were drawn from those of the natural flora observed on cold-smoked salmon. For instance, M2 did not contain Lactobacillus spp which sometimes occur late after the onset of spoilage, M5 was designed to provide a rough approximation of the actual proportion of the flora at the beginning of storage.

The results showed that Lactobacillus spp. developed well on cold-smoked salmon, reaching about $8.5 \log \mathrm{cfu} \mathrm{g}^{-1}$. In mixtures with other bacteria, Lactobacillus spp. were able to dominate the bacterial flora at the end of the storage period, as indicated by high bacterial counts and low $\mathrm{pH}$ values. These findings are in agreement with reports in the literature in which the predominance of Lactobacillus spp. was observed at the end of the shelf life of naturally contaminated smoked salmon (Civera et al., 1995; Truelstrup Hansen, 1995; Truelstrup Hansen et al., 1995, 1996, 1998; Leroi et al., 1998). The Lactobacillus group occupied a central position on the first and second PCA planes showing that their growth did not result in a larger production of any particular compounds. On the other hand, Lactobacillus spp. containing combinations M3, M4, and M5 released large amounts of volatile compounds, such as acetic acid, ethyl acetate and n-propyl acetate. Any or all of these compounds could have been responsible for the odours perceived (sour, acid, pungent) when samples containing the three species of Lactobacillus were found to be spoiled after 40 days of storage. A dihydrogen sulphide smell was also described by the panellists who scored samples inoculated with L. sake. This finding is in agreement with data in the literature indicating that $\mathrm{H}_{2} \mathrm{~S}$ was produced by an $L$. sake strain during growth on cold-smoked salmon 
(Truelstrup Hansen, 1995) and by a homofermentative Lactobacillus sp. on a meat product (Borch and Agerhem, 1992). As this compound is very light, it was poorly or not at all detected by mass-spectrometry, possibly because it was lost during the preparation of the sample or after opening of the bags.

The other genus of lactic acid bacteria, C. piscicola, frequently occurs in cold-smoked salmon flora. Carnobacterium spp. were previously found to predominate in vacuum-packed lightly preserved fish products such as sugar-salted salmon (Leisner et al., 1994) and cold-smoked salmon (Leroi et al., 1998). In our experiment, this bacterium produced the greatest amount of 2,3-butanedione and 2,3-pentanedione, two substances which in pure condition give off a strong butter odour. Thus, these compounds could explain the butter odour noted by the panellists. A butter smell from Carnobacterium sp. has also been reported for meat products (Borch et al, 1996). Because these smells are not particularly unpleasant, the samples were not regarded as spoiled. Thus, a high level of $C$. piscicola growth did not lead to spoilage of the smoked salmon. These findings are in agreement with those of other studies in which Carnobacterium sp. were found in large number or were copiously inoculated into smoked salmon without affecting the sensory quality (Leroi et al., 1996; Paludan-Müller et al., 1998; Nilsson et al., 1999).

B. thermosphacta, which is associated with the spoilage of refrigerated meat products (Borch et al., 1996), has been detected in cold-smoked fish (Cann et al., 1984; Truelstrup Hansen, 1995; Truelstrup Hansen et al., 1996; Leroi et al., 1998), though usually in relatively low numbers. The present study showed that $B$. thermosphacta was clearly distinct from the other species, producing higher amounts of 2-heptanone and 2-hexanone, which were probably responsible for the blue-cheese odour detected by the sensory panel. The same strains of $B$. thermosphacta produced strong spoilage odours (sour, blue cheese, and butyric-acid-like) when cultured in sterile smoked salmon extract juice (Leroi et al., 1998). 
Gram-negative bacteria and combinations M1 and M2 gave off relatively high levels of volatile compounds, such as TMA, disulphide dimethyl, 2,3-butanediol and 2-pentanol. These compounds were probably responsible for amine, sock and floorcloth odours in samples inoculated with Aeromonas sp., Enterobacteriaceae and M2, which were considered to be spoiled after 40 days of storage.

S. putrefaciens, a spoilage bacterium for fresh fish and meat products, is known to produce volatile compounds such as TMA from the TMAO present in fish muscle and sulphurous compounds, especially disulphide dimethyl (Miller et al., 1973; Dainty and Mackey, 1992; Gram and Huss, 1996). In our study, both of these compounds produced off-odours of the type usually found at spoilage. The five strains used in our study were previously grown in sterile smoked salmon extract juice (Leroi et al, 1998) where they produced strong off-odours $\left(\mathrm{H}_{2} \mathrm{~S}\right.$, putrid). On the other hand, sterile smoked salmon inoculated with a mixture of the five strains was not clearly spoiled in the present study after 40 days of storage. Moreover, in naturally contaminated cold-smoked salmon, S. putrefaciens is dominated by gram-positive bacteria and lactic acid bacteria in particular (Cann et al., 1984; Leroi et al., 1998). Thus, this bacterium represents only a small part of the total flora after one or two weeks of storage and does not seem capable of spoiling the product.

Enterobacteriaceae strains inoculated into different cold-smoked salmon models (juice or muscle blocks) displayed a spoilage potential by producing off-odours (the present study; Truelstrup, 1995). These bacteria have been frequently encountered in cold-smoked salmon or trout (Declerck, 1976; Civera et al., 1995; Truelstrup Hansen, 1995; Lyhs et al., 1998), but usually at low levels. However, these bacteria, together with lactic acid bacteria or psychrotrophic marine vibrio, have sometimes been found to dominate the flora (From and Huss, 1991, as cited by Truelstrup Hansen, 1995; Truelstrup et al., 1998). In this case, they 
express their spoilage potential through the production of compounds such as TMA and disulphide dimethyl detected in the present study.

The volatile compounds of biological origin found in smoked salmon inoculated with the different species were also detected in naturally contaminated commercial smoked salmon samples (data not shown), whereas no other volatile compounds of microbial origin appeared in these samples. This indicates that these compounds are relevant to microbial activity and the spoilage of cold-smoked salmon.

In conclusion, this study shows that some bacterial strains isolated from cold-smoked salmon seem to be well-characterised by certain volatile compounds, e.g. C. piscicola by 2,3butanedione (diacetyl) and 2,3-pentanedione, B. thermosphacta by 2-heptanone and 2propanone. Moreover, the relationships between some bacteria, volatile compounds and certain smells were rather precisely defined, e.g. C. piscicola, 2,3-butanedione and butter smell, or B. thermosphacta, 2-heptanone and blue-cheese odour. Such results for cold-smoked salmon should improve our understanding of spoilage mechanisms since they indicate the bacteria mainly responsible for the sensory deterioration of products.

\section{Acknowledgements}

This study was carried out as part of an EU-FAIR project. The authors are grateful to $\mathrm{M}$. Cardinal and J. Cornet for assistance with sensory analysis and to F. Chevalier for technical assistance. 


\section{REFERENCES}

Ben Embarek, PK., 1994. Presence, detection and growth of Listeria monocytogenes in seafoods: a review. International Journal of Food Microbiology 23,17-34.

Borch, E., Agerhem, H., 1992. Chemical, microbial and sensory changes during the anaerobic cold storage of beef inoculated with a homofermentative Lactobacillus sp. or a Leuconostoc sp. International Journal of Food Microbiology 15, 99-108.

Borch, E., Kant-Muermans, ML., Blixt, Y., 1996. Bacterial spoilage of meat and cured meat products. International Journal of Food Microbiology. 33, 103-120.

Cann, D.C., Houston, N.C., Taylor, L.Y., Smith, G.L., Smith, A.B., Craig, A., 1984. Studies of salmonids packed and stored under a modified atmosphere. Report of the Torry Research Station, Aberdeen, Scotland.

Civera, T., Parisi, E., Amerio, G.P., Giaccone, V., 1995. Shelf life of vacuum-packed smoked salmon: microbiological and chemical changes during storage. Archiv Für Lebensmittelhygiene. 46, 1-24.

Dainty, R.H., Mackey, B., 1992. The relationship between the phenotypic properties of bacteria from chilled-stored meat and spoilage process. Journal of Applied Bacteriology (Symposium Supplement). 73, 103S-114S.

Declerck, D., 1976. Organoleptic, chemical and microbiological aspects of vacuum packed and unpacked smoked pink salmon. Medelingen Van Het Rijksstation Voor Zeevisserij (C.L.O.Gent) Publikatie nr. 113-VB/VV(I.W.O.N.L.). 18, 1-9. 
Elliker, P.R., Anderson, A.W., Hannesson, G., 1956. An agar culture medium for lactic acid Streptococci and Lactobacilli. Journal of Dairy Science. 39, 1611-1612.

Gram, L., Huss, H.H., 1996. Microbiological spoilage of fish and fish products. International Journal of Food Microbiology. 33, 121-137.

Heinitz, M.L., Johnson, J., 1998. The incidence of Listeria spp., Salmonella spp., and Clostridium botulinum in smoked fish and shellfish. Journal of Food Protection. 61(3),318-323.

Hildebrandt, G.V., Erol, I., 1988. Sensorische und mikrobiologische Untersuchung an vakuumverpackten Räucherlachs in Scheiben (Sensory and microbiological analysis of vacuum packed sliced smoked salmon). Archiv Für Lebensmittelhygiene. 39, 120123.

Huss, H.H., Ben Embarek, P.K., From Jeppensen, V., 1995. Control of biological hazards in cold smoked salmon production. Food Control. 6, 335-340.

Joffraud, J.J., Leroi, F., Chevalier, F., 1998. Development of a sterile cold-smoked fish model. Journal of Applied Microbiology. 85, 991-998.

Jorgensen, L.V., Huss, H.H., 1998. Prevalence and growth of Listeria monocytogenes in naturally contaminated seafood. International Journal of Food Microbiology. 42, 127131.

Kondjoyan, N., Berdagué, J.L., 1996. A compilation of relative retention indices for the analysis of aromatic compounds. Edition du Laboratoire Flaveur. Station de Recherche sur la viande, INRA de Theix, St Genes Champanelle, France. 234 p. 
Leisner, J.J., Millan, J.C., Huss, H.H., Larsen, L.M., 1994. Production of histamine and tyramine by lactic acid bacteria isolated from vacuum-packed sugar-salted fish. Journal of Applied Bacteriology. 76, 417-423.

Leroi, F., Arbey, N., Joffraud, J.J., Chevalier, F., 1996. Effect of inoculation with lactic acid bacteria on extending the shelf-life of vacuum-packed cold-smoked salmon. International Journal of Food Science and Technology. 31, 497-504.

Leroi, F., Joffraud, J.J., Chevalier, F., Cardinal, M., 1998. Study of the microbial ecology of cold smoked salmon during storage at $8^{\circ} \mathrm{C}$. International Journal of Food Microbiology. 39, 111-121.

Lyhs, U., Björkroth, J., Hyytiä, E., Korkeala, H., 1998. The spoilage flora of vacuumpackaged, sodium nitrite or potassium nitrate treated cold smoked rainbow trout stored at $4^{\circ} \mathrm{C}$ or $8^{\circ} \mathrm{C}$. International Journal of Food Microbiology. 45, 135-142.

de Man, J.C., Rogosa, M., Sharpe, M.E., 1960. A medium for the cultivation of Lactobacilli. Journal of Applied Bacteriology. 23, 130-135.

Miller, A., Scanlan, R.A., Lee, J.S., Libbey, L.M., 1973. Volatile compounds produced in sterile fish muscle(Sebastes melanops) by Pseudomonas putrefaciens, Pseudomonas fluorescens, and an Achromobacter species. Applied Microbiology. 6, 18-21.

Nieper, L., 1986. Untersuchung und Beurteilung von vakuumverpacktem geräuchertem Lachs im Hinblick auf die deklarierte Mindesthaltbarkeit.(Analysis and assessment of vacuum packed smoked salmon with regard to the declared minimal shelf life). Rundschau für Fleischuntersuchung und Lebensmittelüberwachung. 38, 135-136. 
Nilsson, L., Huss, H.H., Gram, L., 1999. Growth control of Listeria monocytogenes on coldsmoked salmon using a competitive lactic acid bacteria flora. Journal of Food Protection. 62, 336-342.

Paludan-Müller, C., Dalgaard, P., Huss, H.H., Gram, L., 1998. Evaluation of the role of Carnobacterium piscicola in spoilage of vacuum and modified atmosphere-packedsmoked salmon stored at $5^{\circ} \mathrm{C}$. International Journal of Food Microbiology. 39, 155166.

Rakow, D., von. 1977. Bemerkungen zum Keimgehaltvon im Handel befindlichen Räucherfischen. Archiv für Lebensmittelhygiene. 28, 192-195.

Schulze, Kv., Zimmermann, T., 1983. Untersuchungen an Räucherfischen unter besonderes Berücksichtigung von Makrelen (Analysis of smoked fish with special emphasis on mackerel). Archiv für Lebensmittelhygiene. 34, 67-70.

van Spreekens, K.J.A., 1974. The suitability of a modification of Long and Hammer's medium for the enumeration of more fastidious bacteria from fresh fisheries products. Archiv für Lebensmittelhygiene. 25, 213-219.

Statistica, 1997. Comprehensive system for statistics, graphics and application development. Version 5.1 for Windows ; Statsoft, Charenton - le - pont, France.

Tranchant, J., 1982. Manuel pratique de chromatographie en phase gazeuse. Editions Masson : 120 Bd St Germain Paris. 301-337.

Truelstrup Hansen, L., 1995. Quality of chilled vacuum-packed cold-smoked salmon. Ph.D. Thesis. Danish Institute for Fisheries Research and The Royal Veterinary and Agricultural University of Copenhagen, Denmark. 
Truelstrup Hansen, L., Drewes Ronved, S., Huss, H.H., 1998. Microbiological quality and shelf life of cold-smoked salmon from three different processing plants. Food Microbiology. 15, 137-150.

Truelstrup Hansen, L., Gill, T., Drewes Rontved, S., Huss, H.H., 1996. Importance of autolysis and microbiological activity on quality of cold-smoked salmon. Food Research International. 29 (2), 181-188.

Truelstrup Hansen, L., Gill, T., Huss, H.H., 1995. Effects of salt and storage temperature on chemical, microbiological and sensory changes in cold-smoked salmon. Food Research International. 28 (2), 123-130. 